\title{
Some factors influencing the quality of practical work in science classrooms
}

\author{
Annemarie Hattingh \\ University of Pretoria, South Africa \\ Colleen Aldous and John Rogan \\ University of KwaZuluNatal, South Africa
}

\begin{abstract}
The Science Curriculum Statements of Curriculum 2005 in South Africa emphasise experimentation and problem solving - that is 'doing science'. Data on the implementation of the science component of the new curriculum were obtained from a sample of Mpumalanga secondary schools. This article focuses on one aspect of implementation - the use made of practical work in the teaching of natural science. It describes the quality of the practical work implemented by science teachers, and then goes on to isolate school capacity factors that may influence and predict learner-centred, inquiry types of practical work in science teaching. The most prominent factor appears to be the teachers' perceptions of their learners. Also important, but to a lesser extent, is the attitude of teachers towards innovation. A well functioning school also appears to be an important factor.
\end{abstract}

\section{Introduction}

The Natural Science section of the South African Revised Curriculum Statements of Curriculum 2005 (C2005) place a strong emphasis on 'doing science', as opposed to learning about the facts and theories of science. The relevant outcome, the first of three, is stated thus: "Learners act confidently on their curiosity about natural phenomena; they investigate relationships and solve problems in science, technology and environment contexts." (Department of Education, RSA, 2002). The document goes on to elaborate on this outcome by providing grade-specific standards in three major strands:

- Planning investigations;

- Conducting investigations and collecting data, and

- Evaluating data and communicating findings.

While the previous science syllabi did prescribe practical work, the new curriculum statements go well beyond that which was previously required. For example, the actual planning of investigations or the critical evaluation of methodology and data were never a requirement. Most of the previous practical work, if done at all, involved the following of instructions provided in a worksheet. In the past, practical work was never examined, but with Curriculum 2005 , 'doing science' is one of three major outcomes, all of which are required to be assessed every year.

Previous studies have described the kinds of practical work done in some southern African classrooms, either by means of a single school case study (See for example Rogan, 2007) or multi-school case studies (See for example Kapenda, Kandjeo-Maenga, Kasandra \& Lubben, 2002; Rogan, 2004; Rogan \& Aldous, 2005). The purpose of this paper is somewhat different. Using a large sample, we explore factors which correlate with the quality of practical work being undertaken. These factors are based on the capacity of the school, and are derived from a framework of curriculum implementation proposed by Rogan and Grayson (2003). Which of numerous possible indicators of the capacity of a school to implement C2005 correlate best with the quality of science practical work being undertaken in that school? An understanding of these relationships might well facilitate the implementation of the 'doing of science' outcome of C2005. 


\section{Theoretical framework of the study}

The conceptual framework used in this research is largely based on school improvement research, which in turn is underpinned by theories situated in the change literature (e.g. Fullan, 1991; Hargreaves \& Hopkins, 1991; Spady, 1994; Verspoor, 1989). The framework of curriculum implementation developed by Rogan and Grayson (2003), with the characteristics of a developing country in mind, was used to design the research instrument and guide the analysis. (See figure 1).

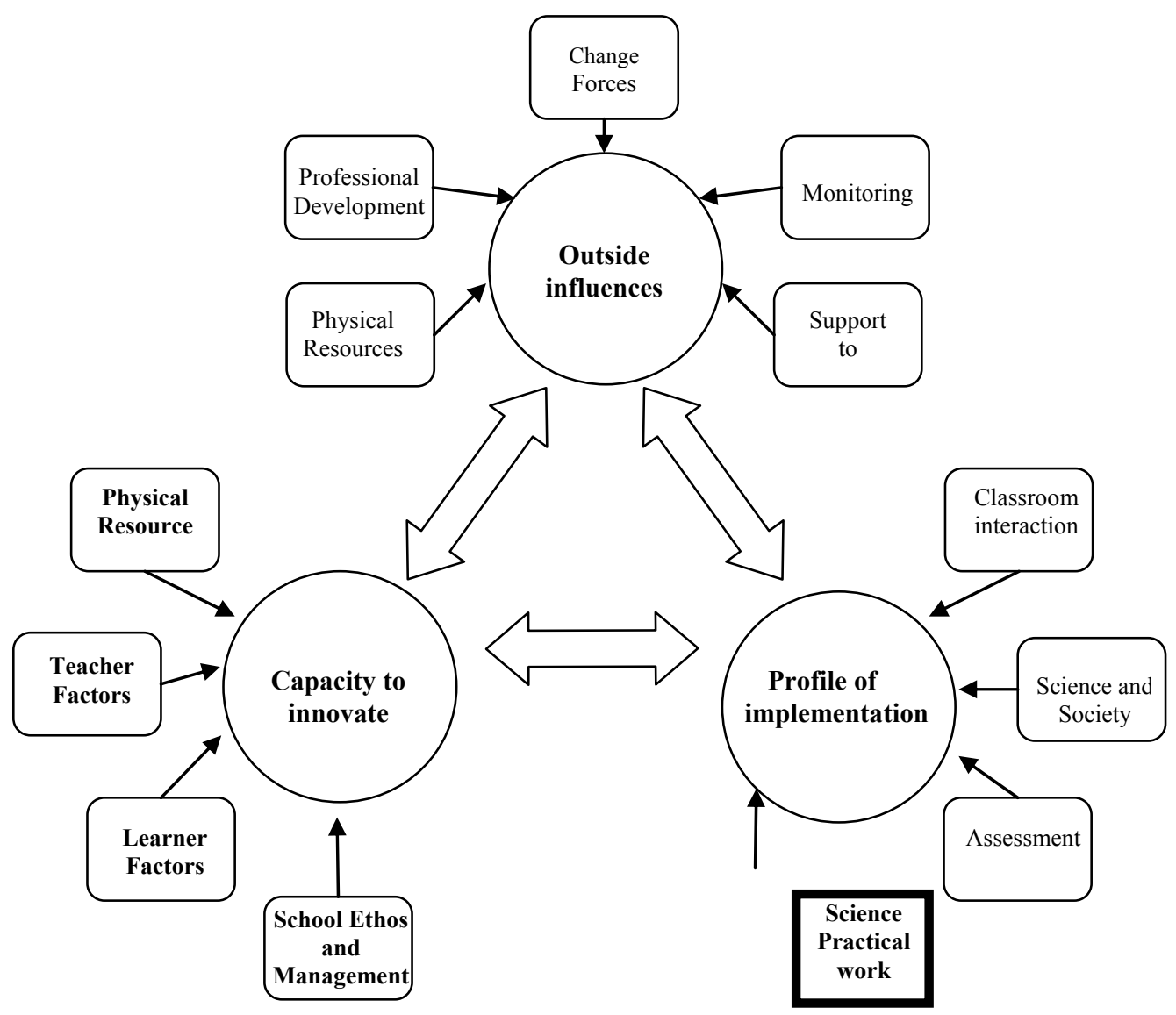

Figure 1: Framework of Curriculum Implementation

(Rogan \& Grayson, 2003). Parts of the framework analysed in this study are shown in bold.

The framework has at its heart three constructs namely a Profile of Implementation, Capacity to Innovate and Outside Support. Each of the three constructs can be utilised to help understand, analyse and express the extent to which the ideals of a curriculum, in this case the science learning area of $\mathrm{C} 2005$, are being realised in context. The construct 'Capacity to Innovate' consists of four sub-constructs; physical resources, teacher factors, learner factors and school ethos and management. The construct 'Outside Influences' consists of five subconstructs; professional development, provision of resources required for the innovation, types of pressures and support brought to bear (change forces), direct support to learners and monitoring strategies.

The four sub-constructs of the Profile of Implementation are: the nature of classroom interaction (what teachers and students do in relation to one another); use and nature of science 
practical work; incorporation of science in society; and assessment practices. Each subconstruct comprises four levels, where level 4 is representative of sophisticated learner-centred practices. In moving through the levels, there is an increasing emphasis towards learnercentred approaches and away from teacher-centred ones. However, unlike the earlier developmental models, the profile does not imply 'progressing' from one level to another and is therefore not linear. Rather, the higher levels are inclusive of the lower practices. Hence the levels are not prescriptive of what should be done at any given point in time, but rather suggest the mastery use of an ever-increasing repertoire of teaching and learning practices. This implies that a teacher may for example, depending on a particular situation, jump from level 2 practices to level 4 practices and back to level 3. It is important to note that level 4 practices are not superior to level 1 practice such as teacher-directed demonstrations to large classes. All practices have merit in science education, and may be used to achieve the outcomes of C2005.

In this study, we concern ourselves only with one of the four sub-constructs of the Profile of Implementation, science practical work, and the relationships between this sub-construct and the four capacity factors. An example of what might constitute each of the four levels of science practical work in the Profile of Implementation is shown in Table 1.

Table 1: Four levels of complexity in science practical work: A classification framework

\begin{tabular}{|c|c|}
\hline Level & Types of science practical work \\
\hline 1 & $\begin{array}{l}\text { Teacher uses classroom demonstrations to help develop concepts. } \\
\text { Teacher uses specimens found in the local environment to illustrate lessons. }\end{array}$ \\
\hline 2 & $\begin{array}{l}\text { Teacher uses demonstrations to promote some form of learner inquiry. } \\
\text { Some learners assist in planning and performing the demonstrations. Learners participate in } \\
\text { closed (cook-book) practical work. } \\
\text { Learners communicate data using graphs and tables. }\end{array}$ \\
\hline 3 & $\begin{array}{l}>\quad \begin{array}{l}\text { Teacher designs practical work in such a way as to encourage learner discovery of } \\
\text { information. }\end{array} \\
>\quad \text { Learners perform guided discovery type practical work in small groups engaging in hands-on } \\
\text { activities. } \\
>\quad \text { Learners can write a scientific report in which they can justify their conclusions based on the } \\
\text { data collected. }\end{array}$ \\
\hline 4 & $\begin{array}{l}\text { Learners design and do their own 'open-ended' investigations. } \\
\text { Learners reflect on the quality of the design and data collected and make improvements } \\
\text { when and where necessary. } \\
\text { Learner can interpret data in support of competing theories or explanations. }\end{array}$ \\
\hline
\end{tabular}

As a working definition, the types of practices described in Table 1 constitute practical work for the purposes of this study. This definition is in line with that of Millar, Le Maréchal and Tiberghien (1998) who take a broad view of practical work as "those teaching and learning activities in science which involve students at some point in handling or observing real objects or materials (or direct representations of these)" (p. 36). The definition of practical work is further operationalised by the items in the questionnaire shown in Table 3.

The idea of using a classification framework, such as Table 1, for understanding and analysing the types of interactions in a school science classroom or laboratory is not new in science education literature (e.g. Eggleston, Galton \& Jones, 1975; Hacker, 1984; Hegarty-Hazel, 1990; Giddings, Hofstein \& Lunetta, 1991). Woolnough and Allsop's (1985) classification framework divide practical work into four groups: exercises, experiences, investigations and illustrations of theory. Kirschner and Meester (1988) have suggested a four-way classification system to analyse types of practical work namely: formal (used to illustrate concepts and laws), experimental (open-ended), divergent (from a common start) and process-skills related. The use of the concept 'levels of inquiry' is also familiar in the practical work discourse and had been made popular by the work of Herron (1971) that described problems or procedures as open or closed (given). We have developed a classification system of types of practical work 
seen in Table 1 to be aligned with the activities and outcomes that learners have to demonstrate as described in C2005 (Department of Education, RSA, 2002) and we have used levels as a way of describing the shift from teacher-directed to learner-centred activities.

According to Kapenda et al. (2002) the desirable characteristics of practical work in developing countries have been highlighted by authors such as Kahn (1990) and Swain, Monk and Johnson (1999). However little is known about what practical activities are actually executed in most African classrooms, and even less about factors which might facilitate their implementation. In this paper we use the classification framework in Table 1 to gauge the types of practical work that teachers in this particular sample execute in their classrooms, and how these levels correlate with school capacity factors.

\section{Context of the study}

The research reported in this paper is part of a 6-year project called the Mpumalanga Secondary Science Initiative (MSSI), which commenced in 1999 and ended in 2006. MSSI was a project of the Mpumalanga Department of Education, which was supported financially by the Japanese International Cooperation Agency (JICA) and professionally by the Universities of Hiroshima, Naruto and Pretoria. The overall goal of this donor-aided project was to enhance the quality of teaching and learning of mathematics and science in all secondary schools in the province in line with the outcomes of C2005. It aimed to achieve this goal by developing an in-service system, with particular focus on school or cluster-based professional development. During the first three years of the project, only grades 8 and 9 were involved. The project was extended to include FET teachers during the final three years.

\section{Research methods}

The research reported in this article is part of a larger study which combined a number of methodologies including surveys, case studies and classroom observation. The research question for this article calls for data on trends prevalent in the Province as a whole. Hence only the method used in designing the survey will be reported on here, although case study results published elsewhere will be referred to in the discussion.

\section{Instrument}

A teacher questionnaire based on the framework shown in Figure 1 was designed during a twoday workshop that included researchers from the USA, the Netherlands, Japan and South Africa. Validity claims for the instrument rest on the extent to which the items in the questionnaire capture the intent of each of the sub-constructs of the framework. The first version of this questionnaire was piloted and then administered in 2001. The reliability of the questionnaire was enhanced by a factor analysis of the "capacity" items of the first version, resulting in the exclusion of weak items (i.e. those items that did not load on any of the emerging groups of items) and the modification of others. The revised version of the questionnaire was used in the study reported in this article. All the "capacity" items are shown in the appendices.

\section{Sample}

In 2002, 117 science teachers of grades 8 and 9 in Mpumalanga completed the revised questionnaire. (Mathematics teachers were included in the survey as well, but their results are not reported here.) The questionnaires were hand delivered to 14-20 schools in each of nine Mpumalanga districts by the curriculum implementer of that district, and collected as soon as they had been completed. All the grade 8 and 9 science and mathematics teachers in each of these schools completed the questionnaire. The sample of schools in each district was selected by the curriculum implementer, or in one case the district manager. They were asked to ensure that the schools that they selected were representative of the types of schools in their district in terms of distinctions such as urban/rural, how well resourced the schools were, and former 
designation such as Department of Education and Training (schools exclusively for black learners, Transvaal Education Department (schools exclusively for white learners) and so on.

\section{Analysis}

In the questionnaire, teachers were asked to estimate what percentage of their teaching time was allocated to practical work and also what percentage of their practical work teaching time was allocated to each of the different levels of practical work practices as defined by items shown in Table 3. These percentages were scaled where necessary, meaning that when summed they had to add up to a hundred percent. The "science practical work" measure was calculated by weighting (according to the level) and summing these percentages. A score for each teacher was determined using the formula:

$$
\text { Item } 1 \% x 1+(\text { Item } 2 \% x 2+\text { Item } 3 \% x 2) / 2+\text { Item } 4 \% x 3+\text { Item } 5 \% x 4 .
$$

A low "science practical work" number indicates mostly level 1 practices, while a high number indicates a substantial proportion of learner-centred practices. The lowest possible number is 100 , which would mean only level 1 practices were present. The higher the sum, the greater the use of higher level practices. The maximum score would be $400[0 \% \times 1+(0 \% \times 2+0 \% \times 2) / 2+$ $0 \% \times 3+100 \% \times 4]$. The questionnaire also had an open-ended section where teachers could explain the practical work practices they engaged in if they could not relate to any of the practices described in the questionnaire. Teachers were also asked to clarify their own descriptions with examples of the type of practical work that they performed.

The "science practical work" score was correlated with each of the "capacity" items. It was then used as the dependent variable in a series of multiple stepwise regression analyses with all the items in each of the sub-constructs of "capacity" in turn.

\section{Results}

The quantity and types of practical work employed by science teachers

Table 2 indicates the number of teachers in the sample who claimed to engage in any type of practical work.

Table 2: Number of teachers using practical work when teaching science

\begin{tabular}{|l|l|l|}
\hline & Frequency & Percentage (\%) \\
\hline Teachers using practical work & 98 & 83.76 \\
\hline Teachers NOT using practical work & 19 & 16.24 \\
\hline
\end{tabular}

The teachers $(83.76 \%)$ who claimed to engage their learners in practical work were asked to estimate the time they spend on the different types of practical work on the different levels. Table 3 indicates the average percentage of practical work time on particular types of practices related to the four different levels. The 19 who reported that they never did any kind of practical work were dropped from this and the following correlational analyses.

The most frequently used practice is the performance of demonstrations by the teacher - a level 1 practice, where the learners mainly observe the teacher who executes the demonstration. Items 2 and 3 describe level two practices where teachers still do demonstrations, but involve learners in different ways, both intellectually and technically. Learners get the opportunity to either manipulate the apparatus or to engage with the data. Item 4 describes a level 3 practice where learners work in groups, basing their actions on the instructions provided by a teacher or a worksheet. This item proved to have the second highest frequency of use. Lastly item 5 describes level 4, the least frequent of the practices, where learners have to design and execute their own investigations and verify the accuracy of their data. 
Table 3: The items used to gauge science practical work, along with their level and average percentage of use

\begin{tabular}{|l|l|c|c|}
\hline Types of practical work & Level & $\begin{array}{l}\text { Average } \\
\text { percentage of } \\
\text { time spent on a } \\
\text { practice }\end{array}$ \\
\hline Item 1 & $\begin{array}{l}\text { Teacher performs a demonstration using bought or improvised } \\
\text { apparatus or biological specimens. }\end{array}$ & 1 & $26.52 \%$ \\
\hline Item 2 & $\begin{array}{l}\text { Teacher performs demonstrations, but with learner participation, and } \\
\text { these demonstrations promote inquiry (thinking) rather than just } \\
\text { illustrate concepts. }\end{array}$ & 2 & $21.71 \%$ \\
\hline Item 3 & $\begin{array}{l}\text { Learners use data from demonstrations to construct their own graphs } \\
\text { and tables. }\end{array}$ & 2 & $17.25 \%$ \\
\hline Item 4 & $\begin{array}{l}\text { Learners perform practical work in groups using apparatus and are told } \\
\text { what to do, either by the teacher or a worksheet. }\end{array}$ & 3 & $20.95 \%$ \\
\hline $\begin{array}{l}\text { Learners perform practical work in groups using apparatus. They are } \\
\text { given a problem or question and they then design their own experiment } \\
\text { and ensure that their data is accurate. }\end{array}$ & 4 & $11.83 \%$ \\
\hline
\end{tabular}

The frequencies of the science practical work scores computed for each of the teachers according to the formula shown above are given in Figure 2. Those that scored in the low hundreds confined their practical work mostly to level 1, teacher performed demonstrations. On the other hand those with scores in the low to mid two hundreds for the most part used a variety of practices, mostly a mixture of levels 1 to 3 .

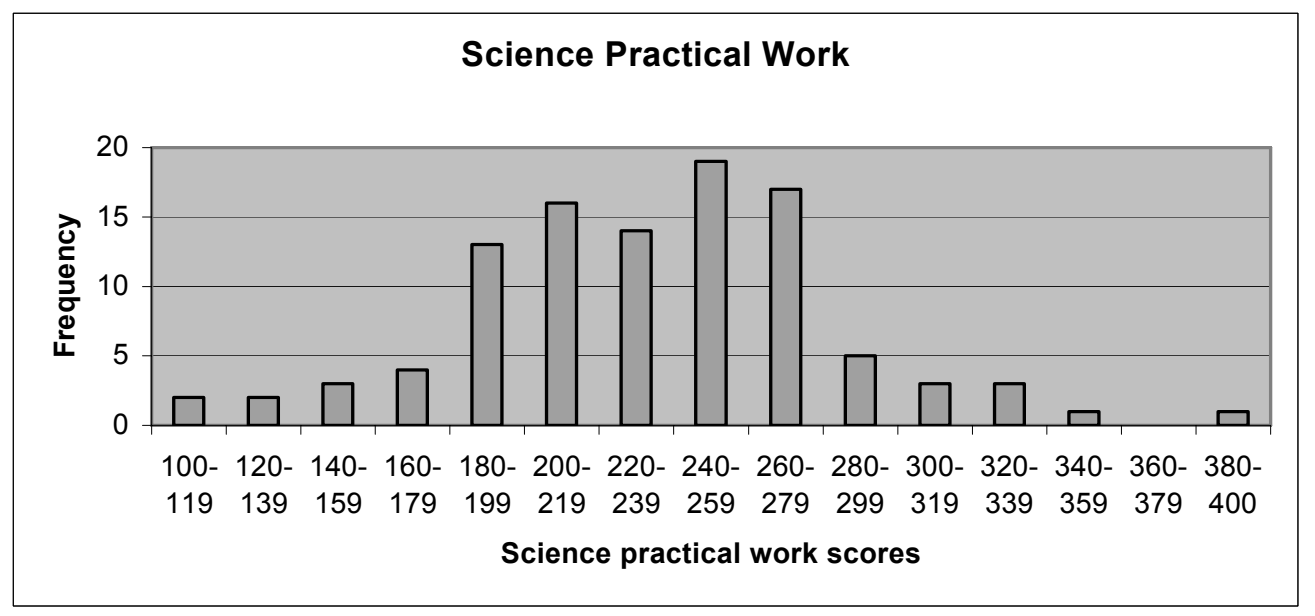

Figure 2: Frequencies of the science practical work scores

\section{Factors influencing teachers' use of practical work in science teaching}

Multiple stepwise regression is a procedure that determines which set of independent variables, in this case the "capacity" items (See Figure 1), best correlates with the dependent variable, in this case the practical work score of the Profile of Implementation. The most important statistic to look for is R-squared for the model - the higher R-squared the greater the relationship between the set of independent variables and the dependent variable. If R-squared for example is 0.25 it means that $25 \%$ of the variance in the dependent variable can be explained by that set of independent variables.

\section{Capacity - Teacher factors}

All "Capacity - Teacher factor" items, together with their correlations with the science practical work score are shown in Appendix I. A stepwise multiple regression for science practical work yielded the model shown in Table 4. Only one variable (V131: In my school, 
teachers are willing to try new teaching methods), proved to be a predictor of "Science Practical Work" from the set of variables shown in Appendix I. R-squared for this model was 0.04 .

Table 4: Regression model for science practical work of the teacher factors

\begin{tabular}{|l|r|c|c|c|c|c|}
\hline \multicolumn{1}{|c|}{ Source } & df & Sum of Squares & Mean square & F value & P value & R-squared \\
\hline Model & 1 & 7920 & 7920 & 3.41 & 0.068 & 0.04 \\
Residual & 87 & 201974 & 2322 & & & \\
Total & 88 & 209894 & & & & \\
\hline
\end{tabular}

\section{Capacity - Learner Factors}

All "Capacity - Learner factor" items, together with their correlations with the science practical work score are shown in Appendix II. These items reflect the teachers' perceptions of their learners. A stepwise multiple regression for science practical work yielded the model shown in Table 5. Variables V271 (My learners have repeated at least one year) with a negative correlation, V266 (My learners are proficient in the language of instruction) with a negative correlation, and V263 (My learners are motivated to study) proved to be predictors of "Science Practical Work". R-squared for this model was 0.24.

Table 5: Regression model for science practical work of the learner factors

\begin{tabular}{|l|r|c|c|c|c|c|}
\hline \multicolumn{1}{|c|}{ Source } & df & Sum of Squares & Mean square & F value & P value & R-squared \\
\hline Model & 3 & 41152 & 13717 & 6.96 & 0.0004 & 0.24 \\
Residual & 67 & 132024 & 1971 & & & \\
Total & 70 & 173176 & & & & \\
\hline
\end{tabular}

\section{Capacity - School Management}

All "Capacity - School management" items, together with their correlations with the science practical work score are shown in Appendix III. None of the variables in correlated sufficiently with "Science Practical Work" to provide a predictive model.

\section{Capacity - School Ethos}

All "Capacity - School Ethos" items, together with their correlations with the science practical work score are shown in Appendix IV. The set of variables yielded the multiple regression model shown in Table 6. Only variable V157 (Teachers and learners are in class when they are scheduled to be) proved to be a predictor of "Science Practical Work". R-squared for this model was 0.03 .

Table 6: Regression model for science practical work of the school practice

\begin{tabular}{|l|r|c|c|c|c|c|}
\hline \multicolumn{1}{|c|}{ Source } & df & Sum of Squares & Mean square & F value & P value & R-squared \\
\hline Model & 1 & 5729 & 5729 & 2.50 & 0.117 & 0.03 \\
Residual & 91 & 208456 & 2291 & & & \\
Total & 92 & 214185 & & & & \\
\hline
\end{tabular}

\section{Capacity - Physical Resources}

All "Capacity - Physical Resources" items, together with their correlations with the science practical work composite score are shown in Appendix V. None of these variables correlated sufficiently with "Science Practical Work" to provide a predictive model.

\section{Summary}

The information provided in Tables 4-6 is summarised in Table 7. 
Table 7: The Factors that predict science practical work

\begin{tabular}{|l|l|l|c|}
\hline Capacity Factors & \multicolumn{2}{|l|}{ Item } & $\begin{array}{l}\text { R-squared for } \\
\text { group of items }\end{array}$ \\
\hline Teacher factors & V131 & $\begin{array}{l}\text { In my school, teachers are willing to try new teaching } \\
\text { methods }\end{array}$ & 0.04 \\
\hline Learner factors & V263 & $\begin{array}{l}\text { My learners are motivated to study } \\
\text { My learners are proficient in the language of } \\
\text { instruction } \\
\text { My learners have repeated at least one year }\end{array}$ & 0.24 \\
\hline School ethos & V157 & $\begin{array}{l}\text { Teachers and learners are in class when they are } \\
\text { scheduled to be }\end{array}$ & 0.03 \\
\hline School management & & None & \\
\hline Physical resources & & None & \\
\hline
\end{tabular}

In the discussion to follow, we interpret these findings.

\section{Discussion}

\section{The quantity and types of practical work}

The positive inflation of answers to self-reporting questionnaires is a well-documented phenomenon (e.g. Dobbins, Fahr \& Werbel, 1993; Salvucci, Walter, Conley, Fink \& Saba, 1997). The results presented in Table 3 and Figure 2 paint a far rosier picture of the type and extent of practical work undertaken in schools than we observed during the case studies undertaken at the same time as the questionnaire was administered (Rogan \& Aldous, 2005). However, an interpretation of the results requires that we look beyond the inflation phenomenon as the only explanation. Current thinking about best practice in science education (Department of Education, RSA, 2002) calls for a far wider interpretation of practical work than the formal (used to illustrate concepts and laws) and process approaches described in the Kirschner and Meester (1988) classification system. Hands-on activity is no longer seen as the only way to engage in practical work, and hence to achieve the 'doing science' outcome of the RNCS. C2005 now places as much emphasis on asking questions, planning experiments and interpreting data, as it does on the actual performance of the activity. Hence if learners devise a plan on how to go about answering a particular research question, or to solve a specific problem, they could be operating at level 4 (See Table 1) even if they do not actually carry out the activity.

A second point to consider is that the descriptors of levels in Table 1 are themselves open to multiple levels of interpretation, and that they attempt to describe practices of an outcome that is very new to schools. Hence a respondent might in good faith believe he or she is engaging learners in a level four practice, but which another person views as a level one or two practice. Neither of the two is necessarily guilty of intentional inflation or deflation. Faced with new and unfamiliar curricular demands, the descriptors used in the questionnaire are likely to be very difficult to match to classroom practice. For example, as Rogan (2004) observed, the seating of learners in groups is often seen by teachers as the fulfilment of outcomes-based learning. Hence the high frequencies reported for levels 3 and 4 in Table 2 could well be a result of the fact that the learners were placed in groups, rather than what was actually being accomplished in the groups.

\section{Factors influencing teachers' use of practical work}

If the intentions of the natural science component of C2005 are to be realised, then a significant amount of practical work at levels 3 and 4 will need to be undertaken. This study provides some possible pointers to factors which might facilitate the attainment of teaching and learning at these levels. 
The research question is not about placing a numerical value on the level of practical work, but rather than looking for relationships between the capacity factors and practical work. Provided the level of inflation is relatively uniform across the board, it will not affect the strength of the correlation of the science practical score with other items in the questionnaire. In other words, even although the scores shown in Figure 2 are inflated, this will not make much difference to the correlations reported in Tables 4-7 and the appendices.

\section{Capacity Factors}

It appears that the way in which teachers perceive their learners has the greatest influence of all capacity factors on the level of science practical work performed. Three learner items together accounted for $24 \%$ of the variance in the science practical scores. The best predictor of all these items was "My learners have repeated at least one year" with a negative correlation of 0.33 (See Appendix II). It would appear that repeaters are seen as disruptive, and possibly a nuisance in the class, and hence less practical work is attempted. A second predictor was "My learners are motivated to study." It is not surprising to find that if the learners are perceived to be motivated, higher-level practical work is attempted. The third item, "My learners are proficient in the language of instruction", is of particular interest. The correlation for this item is a negative -0.14 , a weak but statistically significant result. Hence the less proficient the learners are in language the higher the level of practical work, a seemingly paradoxical finding. One explanation would be that in situations where the learners' language skills are weak, teachers rely more on practical work and less on verbal communication.

Two other items significantly influence the level of practical work. It appears that in situations where teachers perceive their colleagues as being willing to "try new teaching methods", they themselves are motivated to do so as well - at least in terms of practical work. The correlation between this item and the science practical score was 0.21 (Appendix I). The second largest, but not statistically significant item in this group was, "In my district teachers from different schools meet often so as to support and encourage one another". The important theme to emerge here is that higher levels of practical work will be achieved in a school where there is an ethos of willingness to innovate, and where teachers collaborated with one another, both within and across schools. The second significant item comes from the "School Ethos and Management" sub-factor: "Teachers and learners are in class when they are scheduled to be." The correlation for this item was 0.18 (Appendix IV). It seems commonsense that higher-level practical work will occur in more functional schools. This finding supports the notion of whole school development. Efforts to improve science teaching in non-functional schools are bound to be unsuccessful.

What may seem surprising is the lack of influence of the availability of physical resources on the level of practical work. The claim is often made by teachers that their ability to do practical work is hampered by the lack of laboratories and science equipment. Yet none of the resources listed in Appendix V had any significant correlation with the science practical scores. The finding here is confirmed by the case studies (Rogan \& Aldous, 2005), where again no relationship was found between the availability of resources and the level of practical work performed. One case study school, for example, had four laboratories, but did zero practical work. This finding suggests that improving the resources will make little difference unless accompanied by other interventions as well. This finding is in line with the Intervention Strategy on Science, Mathematics and Technology Education (Department of Education, 2000, p 3) comment that "throwing resources at schools that are not able to reach even a basic operational level is not a solution, but may even add to the burden of administration struggling to attain minimal standards." 


\section{Implications}

Practical work has the potential to contribute to meaningful learning in science. Outcome one of the natural science learning area of C2005 can only be achieved if practical work, broadly defined, is performed on a regular basis. Learners can gain an understanding from lower level practices of how existing scientific knowledge is confirmed, while the higher levels of practical work can help learners experience how new knowledge claims can be generated and substantiated. However, whether practical work will be conducted, and the types of practical work to be used, depends, not on intentions of policy documents, but on the decisions of science teachers. It appears from the findings that teachers' decisions to use practical work depend on various factors. The most prominent factor appears to be the teachers' perceptions of their learners. Teachers who perceive their learners to be motivated and non-disruptive are more likely to engage learners in higher-level types of practical work. Also important, but to a lesser extent, is the attitude of teachers in the school towards innovation. It would appear that in a school where innovation is generally supported, science teachers engage in higher levels of practical work. A well functioning school also appears to be an important factor.

If learners have the strongest influence in motivating teachers to provide higher level types of practical work, then creative ways can be sought to capitalise on this finding. Our results suggest that the possibility of an upwards spiral exists. In our experience, both as teachers and observers of classroom practice, we have witnessed how excited learners often become when given the opportunity to do interesting hands-on science. Motivated learners in turn motivate teachers, who then provide more interesting kinds of practical work. One professional development strategy that has the potential to promote this upward spiral is to introduce innovative practices directly into the classroom. Instead of these practices being introduced to teachers in a venue that is removed from the classroom, they could be taught to learners with the teachers as participant observers. The Japanese practice of 'lesson study' does in fact take just this approach (Kita, Ndlalane, Nishioka, Ono \& Paulsen, 2007). Teachers, with or without outside support, plan jointly on how to introduce a particular innovation into a classroom. This new lesson is then taught in a real classroom by one teacher while the others act as observers. Finally, the lesson as practised in the classroom is analysed, and improvements suggested. If the learners are excited and challenged by this jointly planned lesson, then all participating teachers are likely to become more motivated. The MSSI project is, in fact, attempting to introduce this technique into Mpumalanga secondary schools.

The other finding that has important implications is that the doing of practical work is not significantly dependent on whether teachers have physical resources (e.g. laboratories, science apparatus or portable laboratory stations). It seems that those who are motivated to do practical work will find ways to do so even in the most poorly resourced of schools. Conversely those who are not motivated will not do practical work even when they have access to the best of resources. At the moment there appears to be no link between the provision of resources and the capacity of teachers. Schools are provided with resources simultaneously whether they want them, and are ready for them, or not. For example, all schools in Mpumalanga were recently supplied with micro-chemistry kits - even junior secondary schools, which end with grade 9, were supplied with these kits although they are designed for the FET phase (grades 10-12). In our case studies we often found boxes of these kits still unpacked. How much more effective it might have been if these kits had been supplied to teachers as part of their professional development programme, and then only when the teacher concerned indicated that he or she was ready, willing and able to use these resources. This implication is, in effect, simply a restatement of policy suggestion made in the Department of Education (2000) document calling for schools to be equipped on the basis of the 'need to have, able to use' principle. 


\section{References}

Department of Education, RSA (2000). Draft Intervention Strategy for science, mathematics and technology education. September 2000.

Department of Education, RSA (2002). Revised National Curriculum Statements Grades R-9: Natural Sciences. Pretoria: Government printer.

Dobbins, G.H., Fahr, J.L. \& Werbel, J.D. (1993). The influence of self-monitoring and inflation of gradepoint averages for research and selection purposes. Journal of Applied Social Psychology, 23, 321-334.

Eggleston, J.F., Galton, M.J. \& Jones, M. (1975). A Science Teaching Observation Schedule. Schools Council Research Series. London: Macmillan.

Fullan, M.G. (1991). The New Meaning of Educational Change. New York, NY: Teachers College Press.

Giddings, G.J., Hofstein, A. \& Lunetta, V. (1991). Assessment and evaluation in the science laboratory. In B. Woolnough (Ed.), Practical Science (pp. 167-177). Buckingham: Open University Press.

Hacker, R.G. (1984). A typology of approaches to science teaching in schools. European Journal of Science Education, 6, 153-167.

Hargreaves, D.H. \& Hopkins, D. (1991). The Empowered School. The management and practice of development planning. London: Cassell Educational Limited.

Hegarty-Hazel, E. (1990). Tertiary science classrooms. In E. Hegarty-Hazel (Ed.). The student laboratory and the science curriculum (pp. 357-382). London: Routledge.

Herron, M.D. (1971). The nature of scientific enquiry. School review, 79, 171-212.

Kahn, M. (1990). Paradigm lost: The importance of practical work in school science from a developing country perspective. Studies in Science Education, 18, 127-136.

Kapenda, H.M., Kandjeo-Marenga, H.U., Kasandra, C.D. \& Lubben, F. (2002). Characteristics of Practical Work in Science Classrooms in Namibia. Research in Science and Technology Education, 20, 53-65.

Kirschner, P. \& Meester, M. (1988). Laboratory approaches. Higher Education, 17, 81-98.

Kita, M., Ndlalane, T., Nishioka, K., Ono, Y. \& Paulsen, R. (2007). Teacher Development and Empowerment through Collaborative Lesson Study: The Experience of MSSI in the Republic of South Africa. In M. Nagao, J.M. Rogan \& M. Magno (Eds.) Mathematics and Science Education in Developing Countries: Issues, Experiences and Cooperation Prospects. Manila: University of Philippines Press.

Millar, R., Le Maréchal, J-F. \& Tiberghien, A. (1998). A Map of the Variety of Labwork. Labwork in Science Education (LSE) Project. Working paper 1. European Commission TSER Programme Project PL95-2005.

Rogan, J.M. (2007). An Uncertain Harvest: A Case Study of Implementation of Innovation. Journal of Curriculum Studies, 39, 97-121.

Rogan, J.M. (2004). Out of the Frying Pan ...? Case Studies of the Implementation of Curriculum 2005 in some Science Classrooms. African Journal of Research in Mathematics, Science and Technology Education, 8, 165-179.

Rogan, J.M. \& Aldous, C.M. (2005). The Relationships between the Constructs of a Theory of Curriculum Implementation. Journal of Research in Science Teaching, 42, 313-336.

Rogan, J.M. \& Grayson, D. (2003). Towards a Theory of Curriculum Implementation with Particular Reference to Science Education in Developing Countries. International Journal of Science Education, 25, 1171-1204.

Salvucci, S., Walter, E., Conley, V., Fink, S. \& Saba, M. (1997). Measurement error studies at the National Center for Education Statistics. Washington D.C.: US Department of Education. 
Spady, W. G. (1994). Outcomes-Based Education: Critical Issues and Answers. Arlington: American Association of School Administrators.

Swain, J., Monk, M. \& Johnson, S. (1999). A comparative study of attitudes to the aims of practical work in science education in Egypt, Korea, and the UK. International Journal of Science Education, 21, 1051-1066.

Verspoor, A. (1989). Pathways to Change: Improving the Quality of Education in Developing Countries. Washington D.C.: The World Bank.

Woolnough, B. \& Allsop, T. (1985). Practical Work in Science. Cambridge: Cambridge University Press. 


\section{Appendix I: Correlation of teacher factor items with "Science Practical Work" scores}

Please indicate to what extent you agree or disagree with the following statements using the scale: $1=$ Strongly Disagree, $2=$ Disagree, $3=$ Agree, $4=$ Strongly Agree

\begin{tabular}{|c|l|c|c|}
\hline & Item & Mean & $\begin{array}{c}\text { Correlation } \\
\text { with Science } \\
\text { Practical } \\
\text { Work }\end{array}$ \\
\hline V132 & $\begin{array}{l}\text { In my school we often discuss ideas and share materials with } \\
\text { colleagues who teach the same subject }\end{array}$ & 3.18 & 0.05 \\
\hline V139 & $\begin{array}{l}\text { Teachers in my school make an extra effort to improve teaching } \\
\text { and learning }\end{array}$ & 3.14 & 0.04 \\
\hline V131 & In my school teachers are willing to try new teaching methods & 3.18 & $0.21^{*}$ \\
\hline V138 & $\begin{array}{l}\text { Teachers in my school participate in professional development } \\
\text { activities }\end{array}$ & 3.03 & 0.03 \\
\hline V140 & $\begin{array}{l}\text { Teachers and learners in my school are respectful towards one } \\
\text { another }\end{array}$ & 2.96 & 0.03 \\
\hline V135 & In my district teachers meet with each other to plan lessons & 2.10 & 0.08 \\
\hline V133 & $\begin{array}{l}\text { In my district teachers from different schools meet often so as to } \\
\text { support and encourage one another }\end{array}$ & 2.56 & 0.17 \\
\hline V134 & Effective school-based in-service training happens at my school & 2.55 & 0.02 \\
\hline V128 & If I were given the opportunity, I would leave teaching this year & 2.23 & 0.04 \\
\hline V130 & Morale in my school is low & 2.41 & 0.00 \\
\hline V129 & $\begin{array}{l}\text { Teachers in my school are available to help students with their } \\
\text { work after official school hours }\end{array}$ & 2.92 & -0.04 \\
\hline V142 & $\begin{array}{l}\text { In my school teachers reprimand learners for providing incorrect } \\
\text { answers eg by calling them stupid }\end{array}$ & 1.55 & -0.11 \\
\hline V141 & $\begin{array}{l}\text { Teachers in my school are often not in the classroom when they } \\
\text { should be }\end{array}$ & 1.78 & -0.12 \\
\hline V137 & $\begin{array}{l}\text { Teachers in my school find it difficult to be present at school on a } \\
\text { regular basis }\end{array}$ & 1.74 & 0.00 \\
\hline V127 & $\begin{array}{l}\text { Teachers should not be expected to work after official school } \\
\text { hours }\end{array}$ & 1.92 & 0.06 \\
\hline *p<0.05 **po & & \\
\hline
\end{tabular}




\section{Appendix II: Correlation of learner factor items with "Science Practical Work" scores}

Please try to estimate the percentage of the learners whom you teach that are described by the following categories.

\begin{tabular}{|c|c|c|c|}
\hline & Item & $\begin{array}{c}\text { Mean } \\
\%\end{array}$ & $\begin{array}{l}\text { Correlation with } \\
\text { Science } \\
\text { Practical Work }\end{array}$ \\
\hline & & & $\mathrm{n}=91-97$ \\
\hline V269 & My learners find science easy & 39 & 0.13 \\
\hline$V 268$ & My learners enjoy mathematics & 50 & 0.20 \\
\hline V267 & My learners enjoy science & 52 & 0.17 \\
\hline V263 & My learners are motivated to study & 51 & 0.14 \\
\hline V270 & My learners find mathematics difficult & 54 & $-0.23 *$ \\
\hline V260 & $\begin{array}{l}\text { The parents (or guardians) of my learners encourage them to } \\
\text { study }\end{array}$ & 36 & -0.09 \\
\hline$V 259$ & $\begin{array}{l}\text { The parents (or guardians) of my learners have a matriculation } \\
\text { (or higher) certificate }\end{array}$ & 28 & -0.07 \\
\hline V266 & My learners are proficient in the language of instruction & 38 & -0.14 \\
\hline V261 & My learners have access to books and magazines at home & 33 & 0.01 \\
\hline V264 & Family duties and obligations keep my learners out of school & 31 & $-0.24 *$ \\
\hline V265 & My learners are old for their grade level & 34 & $-0.22 *$ \\
\hline V271 & My learners have repeated at least one year & 22 & $-0.33^{* *}$ \\
\hline V253 & My learners come to school hungry & 37 & $-0.22 *$ \\
\hline V256 & My learners find it impossible to study at home & 46 & -0.15 \\
\hline V254 & My learners come from homes that have electricity & 65 & 0.10 \\
\hline V255 & My learners come from homes that have running water & 53 & 0.00 \\
\hline V257 & My learners live in a safe neighbourhood & 51 & 0.09 \\
\hline V262 & My learners are able to attend school regularly & 73 & 0.10 \\
\hline V258 & My learners have to travel more that $5 \mathrm{~km}$ to attend school & 42 & -0.18 \\
\hline
\end{tabular}




\section{Appendix III: Correlation of school management items with "Science Practical Work" scores}

Please indicate to what extent you agree or disagree with the following statements using the scale: 1 = Strongly Disagree (SD), $2=$ Disagree, $3=$ Agree, $4=$ Strongly Agree

\begin{tabular}{|l|l|c|c|}
\hline Item & Mean & $\begin{array}{c}\text { Correlation with } \\
\text { Science Practical } \\
\text { Work }\end{array}$ \\
\hline & \multicolumn{1}{|c|}{$\mathrm{n}=96-99$} \\
\hline V143 & I feel that my principal supports me & & -0.06 \\
\hline V144 & I feel that my Head of Department supports me & 3.16 & -0.11 \\
\hline V147 & My principal is a good leader & 3.23 & 0.04 \\
\hline V154 & Staff meetings are beneficial & 3.06 & 0.09 \\
\hline V153 & Staff meetings are held as needed & 3.05 & 0.06 \\
\hline V146 & Staff members are held accountable for their actions & 3.13 & -0.09 \\
\hline V145 & My school has good security & 2.39 & -0.08 \\
\hline V149 & Learners have a say in the running of the school & 2.59 & 0.08 \\
\hline V148 & $\begin{array}{l}\text { Staff participate in the management of the school and } \\
\text { therefore have a say in the running of the school }\end{array}$ & 2.85 & 0.07 \\
\hline V150 & Everyone in my school has a shared vision for the school & 2.72 & 0.09 \\
\hline V151 & Parents are actively involved in the school & 2.57 & 0.03 \\
\hline V152 & The School Governing body is actively involved in the school & 1.90 & 0.10 \\
\hline
\end{tabular}

$* \mathrm{p}<0.05 * * \mathrm{p}<0.01$

\section{Appendix IV: Correlation of school ethos with "Science Practical Work" scores}

Please indicate the extent to which the following occur using the scale: $1=$ Hardly Ever, $2=$ Sometimes,

$3=$ Often, $4=$ Almost Always

\begin{tabular}{|l|l|c|c|}
\hline & \multicolumn{1}{|c|}{ Statement } & $\begin{array}{c}\text { Mea } \\
\mathbf{n}\end{array}$ & $\begin{array}{c}\text { Correlation } \\
\text { with Science } \\
\text { Practical Work }\end{array}$ \\
\hline & \multicolumn{1}{|c|}{} & $\mathrm{n}=97-99$ \\
\hline V155 & In my school we follow the timetable & 3.89 & 0.16 \\
\hline V156 & My Principal is present at my school & 3.68 & 0.06 \\
\hline V157 & $\begin{array}{l}\text { Teachers and learners are in class when they are scheduled to } \\
\text { be }\end{array}$ & 3.37 & 0.18 \\
\hline V158 & Unauthorised people have access to the school & 1.95 & -0.08 \\
\hline V159 & Extramural activities interfere with classes & 1.78 & -0.06 \\
\hline V160 & $\begin{array}{l}\text { At my school staff members who do not carry out their } \\
\text { duties are disciplined. }\end{array}$ & 2.58 & -0.03 \\
\hline V161 & $\begin{array}{l}\text { The Principal walks around to see what is going on in the } \\
\text { school }\end{array}$ & 3.09 & -0.03 \\
\hline
\end{tabular}

${ }^{*} \mathrm{p}<0.05 * * \mathrm{p}<0.01$ 


\section{Appendix V: Correlation of the availability of resources with "Science Practical Work" scores}

Indicate in the table below whether your school has the resources listed.

\begin{tabular}{|l|l|c|c|}
\hline \multicolumn{1}{|c|}{ Resource } & Present & $\begin{array}{c}\text { Correlation with Science } \\
\text { Practical Work }\end{array}$ \\
\hline & & & $\mathrm{n}=87-90$ \\
\hline V208 & Teachers' guides & $75.14 \%$ & 0.11 \\
\hline V210 & Worksheets & $55.09 \%$ & 0.09 \\
\hline V212 & Experimental apparatus & $63.74 \%$ & 0.09 \\
\hline V214 & Laboratory & $50.90 \%$ & 0.01 \\
\hline V216 & Photocopying facilities & $73.68 \%$ & 0.03 \\
\hline V218 & Running water & $69.82 \%$ & 0.04 \\
\hline V220 & Electricity & $81.29 \%$ & 0.11 \\
\hline V222 & Computers & $43.60 \%$ & -0.09 \\
\hline
\end{tabular}

$* \mathrm{p}<0.05 * * \mathrm{p}<0.01$ 